Bueno, F.P. Educação Ambiental e a visitação em parques: um estudo sobre o Parque Estadual do Morro do Diabo. Anais do VIII Congresso Nacional de Ecoturismo e do IV Encontro Interdisciplinar de Ecoturismo em Unidades de Conservação. Revista Brasileira de Ecoturismo, São Paulo, v.4, n.4, 2011 , p. 520.

\title{
EDUCAÇÃO AMBIENTAL E A VISITAÇÃO EM PARQUES: UM ESTUDO SOBRE O PARQUE ESTADUAL DO MORRO DO DIABO
}

\author{
Fernando Protti Bueno* \\ *Universidade Estadual Paulista Júlio de Mesquita Filho - Câmpus Rosana \\ E-mail: fernando@rosana.unesp.br
}

Tratar de educação ambiental no contexto da visitação em unidades de conservação, especificamente na categoria parques, requer a consideração da existência no plano de manejo de um programa de uso público que atenda a visitação pública, tanto voltada ao lazer, ao turismo ou às atividades educativas não-formais. Considerando a importância de conservação da natureza, prioritariamente no extremo oeste do Estado de São Paulo, aonde se localiza o Parque Estadual do Morro do Diabo, um dos últimos remanescentes de floresta de Mata Atlântica da região, tem-se a possibilidade de reflexão acerca dos diferentes meios para prover o uso público e a conservação deste espaço. Em geral, a visitação em parques compreende o contato/ contemplação livre e/ou mediada do visitante com a natureza, oferecendo oportunidades para vislumbrar o potencial educativo e transformador de atividades de educação não-formal e ao ar livre nesse processo de visitação - escolar ou turística. O objetivo desta pesquisa foi analisar junto aos colaboradores do Parque Estadual Morro do Diabo (PEMD) o processo de planejamento e a realização de atividades de educação ambiental no contexto da visitação recreativa ou educativa. Para tanto, adotaram-se como procedimentos metodológicos os métodos dedutivo e monográfico/ estudo de caso, primando pela abordagem qualitativa de pesquisa. Para a coleta e tabulação de dados foram utilizadas as técnicas de pesquisa bibliográfica, documental, de observação assistemática e de entrevista, realizada a partir da técnica do Discurso do Sujeito Coletivo (DSC), por meio da qual foram identificadas as expressões-chaves (ECHs) e selecionadas as idéias centras (ICs) dos discursos provenientes dos colaboradores envolvidos com o programa de uso público do parque. Como resultados de pesquisa indicam-se a existência de subprogramas de educação ambiental e de interpretação da natureza inseridos no programa de uso público do parque. Os discursos provenientes da gestão do parque revelam timidamente o processo pelo qual ocorre o planejamento e a realização da educação ambiental junto aos diferentes públicos visitantes. Os colaboradores que executam e conduzem os grupos de visitantes - turistas ou escolares - revelam que o planejamento da educação ambiental a ser desenvolvida em caminhadas guiadas pelas trilhas existentes, ocorre, principalmente com os grupos escolares, de acordo com o interesse do visitante, sendo que este precisa evidenciar o tema o qual prefere ou necessita que seja abordado, já com o público esporádico - recreação ou turismo - não foi possível constatar um processo de planejamento, muito menos de execução de educação ambiental, apenas a condução dos mesmos pelas trilhas ou ainda com algumas exceções há uma abordagem tradicional ao público, ou seja, a mesma realizada com o público escolar ou ainda o uso habitual de tratar oralmente sobre a importância de se cuidar do meio ambiente. Desse modo, concluiu-se que, assim como em boa parte das unidades de conservação que permitem a visitação, inclusive os parques, as atividades de educação ambiental, mesmo previstas no plano de manejo não decorrem de um processo de educação não-formal sistematicamente definido, o que sugere a dificuldade de alcançar o real potencial educativo e transformador que possui as atividades de educação ambiental.

Palavras-chave: Educação ambiental; Uso público; Unidades de conservação. 